\title{
Peripheral mechanisms of symptom generation in irritable bowel syndrome
}

\author{
Stephen M Collins MBBS FRCPUK FRCPC
}

SM Collins. Peripheral mechanisms of symptom generation in irritable bowel syndrome. Can J Gastroenterol 2001;15(Suppl B):14B-16B. There is considerable interest in the mechanisms that underlie symptom generation in irritable bowel syndrome (IBS) and particularly those mechanisms peripheral to higher centres in the nervous system. While the central nervous system is important in IBS, it is restricted largely to the role of behaviour in stress perception and symptom reporting. The gut and the autonomic nervous system are principal areas of research in identifying mechanisms underlying symptom generation and in the identification of new targets for drug development. While motility changes occur in IBS, they are neither specific nor predictable, and this is one reason why drugs aimed at influencing motility patterns have enjoyed limited success to date. This success has prompted interest in sensory physiology to explain pain and other discomforts expressed by patients with IBS. Patients with IBS exhibit intolerance to rectal distension and other manoeuvres of the gut, while exhibiting normal or raised thresholds for somatic pain. The mechanisms underlying the development of hyperalgesia or allodynia in the gut remain to be determined. In other systems and experimental models, low grade inflammation is a predicable inducer of these states, and recent evidence suggests that a subpopulation of patients with IBS develop chronic symptoms after acute gastroenteritis. This and other inflammatory stimuli may induce a hyperalgesic state and alter motor function in patients with IBS. Substances that mediate these changes are not fully understood, but there is growing recognition of the role of serotonin as a sensitizing agent.

Key Words: Afferent nerves; Gastroenteritis; Inflammation; Irritable bowel syndrome; Muscle contraction; Serotonin

\section{Mécanismes périphériques de l'apparition des symptômes dans le syndrome du côlon irritable}

RÉSUMÉ : On s'intéresse beaucoup aux mécanismes qui sous-tendent l'apparition des symptômes dans le syndrome du côlon irritable (SCI), particulièrement les mécanismes périphériques par rapport aux centres plus évolués du système nerveux. Si le système nerveux central est important dans le SCI, son rôle est pour une bonne part réduit au comportement face à la perception du stress et au signalement des symptômes. L'intestin et le système nerveux autonome sont les principaux éléments de la recherche sur l'identification des mécanismes qui soustendent l'apparition des symptômes et l'identification de nouvelles cibles pour la mise au point des médicaments. Bien que la motilité varie dans le SCI, ces changements ne sont ni spécifiques ni prévisibles et c'est l'une des raisons pour lesquelles les médicaments visant à influer sur la motilité ont connu un succès, quoique limité, à ce jour. Ce succès a suscité l'intérêt pour le domaine de la physiologique sensorielle qui tente d'expliquer la douleur et autres malaises exprimés par les patients atteints de $\mathrm{SCI}$. Ces patients tolèrent mal la distension rectale et autres anomalies des intestins, mais leur seuil de douleur somatique est normal ou élevé. Les mécanismes qui sous-tendent le développement de l'hyperalgésie ou de l'allodynie au niveau de l'appareil digestif restent à élucider. Dans d'autres systèmes et dans des modèles expérimentaux, une légère inflammation peut déclencher ces états et, selon des preuves récentes, chez une sous-population de patients atteints de SCI, les symptômes deviennent chroniques après une gastro-entérite aiguë. Ce stimulus et d'autres stimuli inflammatoires peuvent provoquer un état d'hyperalgésie et modifier la motricité des patients atteints de SCI. Les substances qui influent sur ces changements sont encore mal connues, mais, de plus en plus, on pointe du doigt la sérotonine comme agent sensibilisateur. 
T raditionally, irritable bowel syndrome (IBS) has been viewed as a psychosomatic disorder, with most emphasis having been placed on the 'psyche' rather than the 'somatic' component. This emphasis has promoted a very conservative psychosocial approach to these patients and has, in this author's opinion, retarded the investigation of tangible mechanisms underlying symptom generation that might lead to more selective and efficacious drug treatments. In addition, the recent trend to classify IBS into subgroups based on symptom clustering will likely obscure identifiable pathophysiological trends and mechanisms, because there is no good evidence of any congruency between symptom-based subgroups and putative pathophysiological mechanisms. Thus, while it is appealling to have clinically homogeneous subgroups as entry criteria for therapeutic trials, this approach is problematic because most drugs are likely to show efficacy across these subgroups. Thus, attention should focus on identifying mechanisms of symptom generation and on testing new drugs based on this approach using a broader selection of patients.

\section{PERIPHERAL MECHANISMS IN THE PATHOGENESIS OF IBS}

There have been recent advances in the understanding of processes that may lead to the development of IBS. While it has long been known that some patients develop IBS following an acute illness suggestive of an enteric infection $(1,2)$, it is only recently that a causal relationship has been established. Prospective studies on patients recovering from proven bacterial gastroenteritis have shown that up to $30 \%$ of patients develop a chronic IBS symptom complex (3-5). Physiological studies performed on some of these patients revealed that IBS symptoms are accompanied by changes in rectosigmoid motor and sensory function (6). A recent analysis of a very large family practice database in the United Kingdom found that enteric infection was the highest risk factor recognized to date for the development of IBS with a relative risk of 11.9 [95\% CI 6.7 to 21.0] (7). An animal model of postinfective gut dysfunction has recently been developed in the mouse (8). The findings in this model suggest that after recovery from the infection there are persistent low grade inflammatory changes in the muscularis externa, with the production of prostaglandin $\mathrm{E}_{2}$ and leukotriene $\mathrm{B}_{4}$. Furthermore, inhibition of these mediators after recovery from infection prevented further development of changes in enteric neuromuscular function (9). These findings, if applicable to people, raise the possibility of reversing the changes in gut dysfunction that persist in some patients after enteric infection.

\section{IBS AS A MOTILITY DISORDER}

The notion that IBS is a motility disorder has been the 'modus operandi' for almost 50 years. Several abnormal patterns of motility have been documented in patients with IBS and include changes in the interdigestive migrating motor complex, the presence of clustered contractions in the small intestine (10) and a number of changes in colonic motility (11). However, it is evident that documented changes in motility in patients with IBS are not specific for IBS and are not present in all patients (12-14). In addition, the relationship of altered motility to symptoms such as pain and discomfort is unpredictable (15) and may reflect increased sensory perception (15). Symptoms of altered bowel habit better correlate with altered motility, at least as reflected by measurements of colonic rather than orocecal transit. Colonic transit is accelerated in the proximal and to a lesser extent in the distal colon (16) in diarrhea-dominant IBS patients, and slow gut transit has been shown in a proportion of constipation-predominant IBS patients (17). The locus of abnormality underlying these changes is likely to vary among patients, with the likelihood being that they will reflect changes in the neural or neuroendocrine control of motility, rather than a defect in smooth muscle physiology. There are no convincing data to support a primary abnormality in smooth muscle function in IBS (18). An intriguing possibility is the role of the interstitial cell of Cajal as a locus of abnormality in IBS; the interstitial cell of Cajal is recognized as the pacemaker cell of the gut (19). This strategically important cell would be a potentially useful target for drug therapy, and more work is required in that direction (20). Alterations in afferent nerves are pertinent not only to the concept of hyperalgesia, but also to altered motility via local reflexes. It follows that drugs aimed primarily at sensory targets will have effects on motility through this mechanism. The accompanying changes in motility will need to be evaluated carefully because they may be therapeutically useful or may offset the primary action of the drug.

\section{ABNORMAL EPITHELIAL FUNCTION}

Some diarrhea-predominant patients consume significant amounts of fruit juices or artificially sweetened beverages, and in these patients a reduction in the ingested quantities of these drinks ameliorates symptoms. However, in a subset of these patients, there may be an inability of the intestinal epithelium to absorb fructose or sorbitol; a defect in the absorption of these carbohydrates has been shown (21). The symptomatic response seems to reflect a specific epithelial transport defect rather than a hyperalgesic response to the osmotic load or a motility disturbance in the small intestine (22). A common clinical scenario is the deterioration of IBS following cholecystectomy with diarrhea being the dominant symptom. While this may result from the dysregulation of bile flow into the gut, it may also reflect the increased sensitivity of the intestinal epithelium to the secretory and motor effects of bile acids. Oddsson et al (23) showed that infusions of small quantities of bile acids produced a net secretory response in patients with IBS but not in healthy subjects. This finding rationalizes the use of cholestyramine to treat diarrhea in patients with IBS. Taken together, these observations indicate that there is evidence of epithelial dysfunction in IBS and that the pathophysiology is not restricted to the sensory-motor apparatus - there is involvement of the entire gut wall.

\section{ABNORMAL SENSORY FUNCTION IN IBS}

Although it has long been recognized that IBS patients have low thresholds for balloon distension of the rectum compared with healthy controls (24), it was unclear whether this represented a generalized intolerance of discomfort or a selective hypersensitivity of their gastrointestinal tract. It has been shown that patients with IBS have elevated thresholds for somatic pain and reduced thresholds for visceral pain $(25,26)$. This finding prompted the investigation of increased sensory perception in the gut in IBS (27), and it is accepted that many patients with IBS have a hyperalgesic bowel where even physiological (non-noxious) stimuli may produce discomfort (allodynia). The underlying mechanisms of visceral hyperalgesia appear to be complex, and models have been created based 
largely on animal work involving the urinary bladder or gastrointestinal tract (28). Invariably, these models rely on inflammatory stimuli to induce hyperalgesia in the gut (29). In this model it is believed that inflammatory mediators or other sensitizing agents such as 5-hydroxytryptamine (5-HT) activate nociceptive $\mathrm{C}$ fibres in the gut, most of which are silent under normal conditions, and these fibres transmit impulses that are perceived to be painful. Once activated, subsequent stimulation results in a substantially increased sensory traffic, which, in turn, induces changes in sensory nerve cell bodies in the dorsal root ganglia and spinal cord. These changes persist long after resolution of the inflammatory process. Other agents including 5-HT may also enhance the perception of pain, but the circumstances under which 5 -HT is released to act on nerves remain to be determined. Central factors also influence pain perception, but a discussion of this is beyond the scope of this brief review.

\section{ALTERED CONTROL MECHANISMS IN THE GUT IN IBS}

Studies have shown that the release of cholecystokinin is exaggerated and prolonged in patients with IBS (30), and this is not shared with other gastrointestinal hormones such as motilin. Target organ responsiveness to cholecystokinin is also increased

\section{REFERENCES}

1. Stewart GT. Post-dysenteric colitis. BMJ 1950;1:405-9.

2. Chaudhary NA, Truelove SC. The irritable bowel syndrome. Q J Med 1962;31:307-22.

3. Gwee KA, Graham JC, McKendrick MW, et al. Psychometric scores and persistence of irritable bowel after infectious diarrhoea. Lancet 1996;347:150-3.

4. McKendrick MW, Read NW. Irritable bowel syndrome - post salmonella infection. J Infect 1994;29:1-3.

5. Neal KR, Hebden J, Spiller R. Prevalence of gastrointestinal symptoms six months after bacterial gastroenteritis and risk factors for development of the irritable bowel syndrome: postal survey of patients. BMJ 1997;314:779-82.

6. Bergin AJ, Donnelly TC, McKendrick MW, Read NW. Changes in anorecta function in persistent bowel disturbance following salmonella gastroenteritis. Eur J Gastroenterol Hepatol 1993;5:617-20.

7. Rodriguez LA, Ruigomez A. Increased risk of irritable bowel syndrome after bacterial gastroenteritis: cohort study. BMJ 1999;318:565-6.

8. Barbara G, Vallance BA, Collins SM. Persistent intestinal neuromuscular dysfunction after acute nematode infection in mice. Gastroenterology 1997;113:1224-32.

9. Barbara G, Blennerhassett PA, Collins SM. On the mechanism underlying postinfective intestinal dysfunction. Gastroenterology 1998;114:G2966. (Abst)

10. Kellow JE, Gill RC, Wingate DL. Prolonged ambulant recordings of small bowel motility demonstrate abnormalities in the irritable bowel syndrome. Gastroenterology 1990;98:1208-18.

11. Frexinos J, Bueno L, Fioramonti J, Delvaux M, Staumont G. [Colonic motility in the irritable bowel syndrome]. Gastroenterol Clin Biol 1990;14:18C-23C.

12. Gorard DA, Libby GW, Farthing MJ. Ambulatory small intestinal motility in 'diarrhoea' predominant irritable bowel syndrome. Gut 1994;35:203-10.

13. Gorard DA, Farthing MJ. Intestinal motor function in irritable bowel syndrome. Dig Dis Sci 1994;12:72-84.

14. Katschinski M, Lederer P, Ellermann A, Ganzleben R, Lux G, Arnold R. Myoelectric and manometric patterns of human rectosigmoid colon in irritable bowel syndrome and diverticulosis. Scand J Gastroenterol 1990;25:761-8.

15. Kellow JE, Eckersley CM, Jones MP. Enhanced perception of physiological intestinal motility in the irritable bowel syndrome. Gastroenterology 1991;101:1621-7.

16. Vassallo M, Camilleri M, Phillips SF, Brown ML, Chapman NJ, Thomforde GM Transit through the proximal colon influences stool weight in the irritable bowel syndrome. Gastroenterology 1992;102:102-8.

17. Probert CS, Emmett PM, Cripps HA, Heaton KW. Evidence for the ambiguity of the term constipation: the role of irritable bowel syndrome. Gut 1994;35:1455-8.

18. Camilleri M, Prather CM. The irritable bowel syndrome: mechanisms and in IBS patients (31). Because cholecystokinin has potent effects on gut function, and on motor activity in particular, it is a likely mediator of many postprandial symptoms in IBS. Considerable attention has focused on 5-HT as a putative mediator of gut dysfunction in IBS. This originated from studies in migraine where 5-HT antagonists have become an effective treatment. There are many similarities between IBS and migraine, as well as asthma. In general, 5-HT pathways in the brain are thought to be normal in IBS (32), but in the gut, which is the main source of 5-HT, changes have been documented in the cellular source and release of 5-HT. Changes have been reported that include an increase in enterochromaffin cells in the colon in diarrheapredominant IBS, where there is also increased postprandial release of 5-HT (33). In patients with slow transit constipation, enterochromaffin cells may be reduced. The mechanisms whereby 5-HT contributes to the generation of abdominal symptoms in IBS are complex but include the regulation of gastrointestinal transit as well as the sensitization of afferent nerves and stimulation of secretion by epithelial cells, and these effects are mediated largely via $5-\mathrm{HT}_{3}$ and $5-\mathrm{HT}_{4}$ receptors (34). This has generated considerable activity in the pharmaceutical industry to produce $5-\mathrm{HT}_{3}$ antagonists to modulate pain and diarrhea, and $5-\mathrm{HT}_{4}$ agonists to accelerate transit and facilitate defecation in constipated patients.

a practical approach to management. Ann Intern Med 1992;116:1001-8.

19. Thomsen L, Robinson TR, Lee JC, et al. Interstitial cells of Cajal generate a rhythmic pacemaker current. Nat Med 1998;4:1-4.

20. Huizinga JD, Thuneberg L, Vanderwinden JM, Rumessen JJ. Interstitial cells of Cajal as targets for pharmacological intervention in gastrointestinal motor disorders. Trends Pharmacol Sci 1997;18:393-403.

21. Rumessen JJ, Gudmand-Hoyer E. Functional bowel disease: malabsorbtion and abdominal distress after ingestion of fructose, sorbitol, and fructose-sorbitol mixtures. Gastroenterology 1988;95:694-700.

22. Evans PR, Piesse C, Bak YT, Kellow JE. Fructose-sorbitol malabsorption and symptom provocation in irritable bowel syndrome: relationship to enteric hypersensitivity and dysmotility. Scand J Gastroenterol 1998;33:1158-63.

23. Oddsson E, Rask-Madsen J, Krag E. A secretory epithelium of the small intestine with increased sensitivity to bile acids in irritable bowel syndrome associated with diarrhea. Scand J Gastroenterol 1978;13:409-16.

24. Whitehead WE, Holtkotter B, Enck P, et al. Tolerance for rectosigmoid distention in irritable bowel syndrome. Gastroenterology 1990;98:1187-92.

25. Cook IJ, van Eeden A, Collins SM. Patients with irritable bowel syndrome have greater pain tolerance than normal subjects. Gastroenterology 1987;93:727-33.

26. Accarino AM, Azpiroz F, Malagelada JR. Selective dysfunction of mechanosensitive intestinal afferents in irritable bowel syndrome. Gastroenterology 1995;108:636-43.

27. Mayer EA, Raybould HE. Role of visceral afferent mechanisms in functional bowel disorders. Gastroenterology 1990;99:1688-704.

28. Mayer EA, Gebhart GF. Basic and clinical aspects of visceral hyperalgesia. Gastroenterology 1994;107:271-93.

29. Burton MB, Gebhart GF. Effects of intracolonic acetic acid on responses to colorectal distension in the rat. Brain Res 1995;672:77-82.

30. Sjolund K, Ekman R, Lindgren S, Rehfeld JF. Disturbed motilin and cholecystokinin release in the irritable bowel syndrome. Scand J Gastroenterol 1996;31:1110-4.

31. Kamath PS, Gaisano HY, Phillips SF, et al. Abnormal gallbladder motility in irritable bowel syndrome: evidence for target-organ defect. Am J Physiol 1991;260:G815-9.

32. Gorard DA, Dewsnap PA, Medbak SH, Perry LA, Libby GW, Farthing MJ. Central 5-hydroxytryptaminergic function in irritable bowel syndrome. Scand J Gastroenterol 1995;30:994-9.

33. Bearcroft CP, Perrett D, Farthing MJ. Postprandial plasma 5-hydroxytryptamine in diarrhoea predominant irritable bowel syndrome: a pilot study. Gut 1998:42:42-6

34. Talley NJ. Review article: 5-hydroxytryptamine agonists and antagonists in the modulation of gastrointestinal motility and sensation: clinical implications. Aliment Pharmacol Ther 1992;6:273-89. 


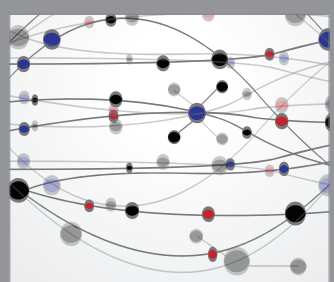

The Scientific World Journal
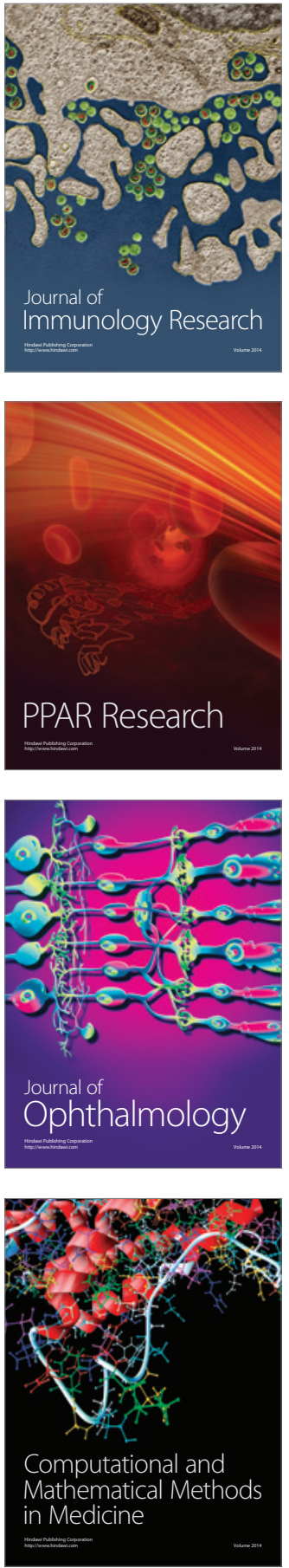

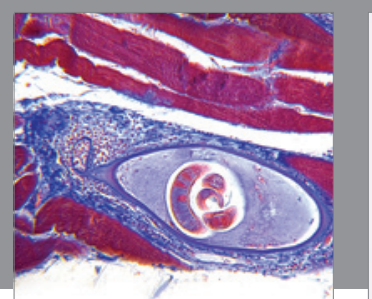

Gastroenterology Research and Practice

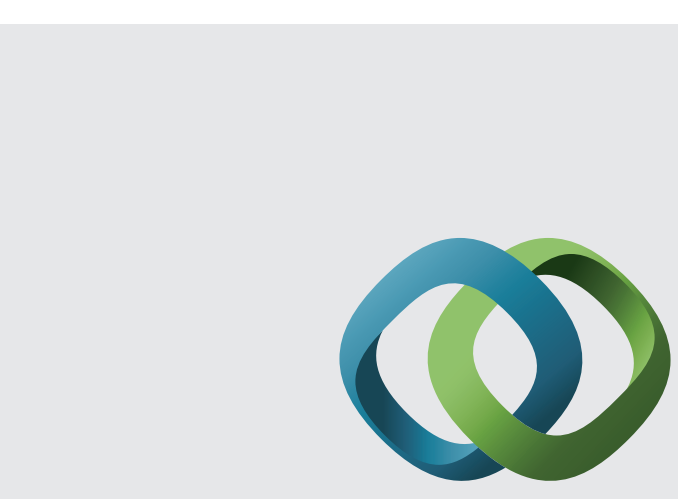

\section{Hindawi}

Submit your manuscripts at

http://www.hindawi.com
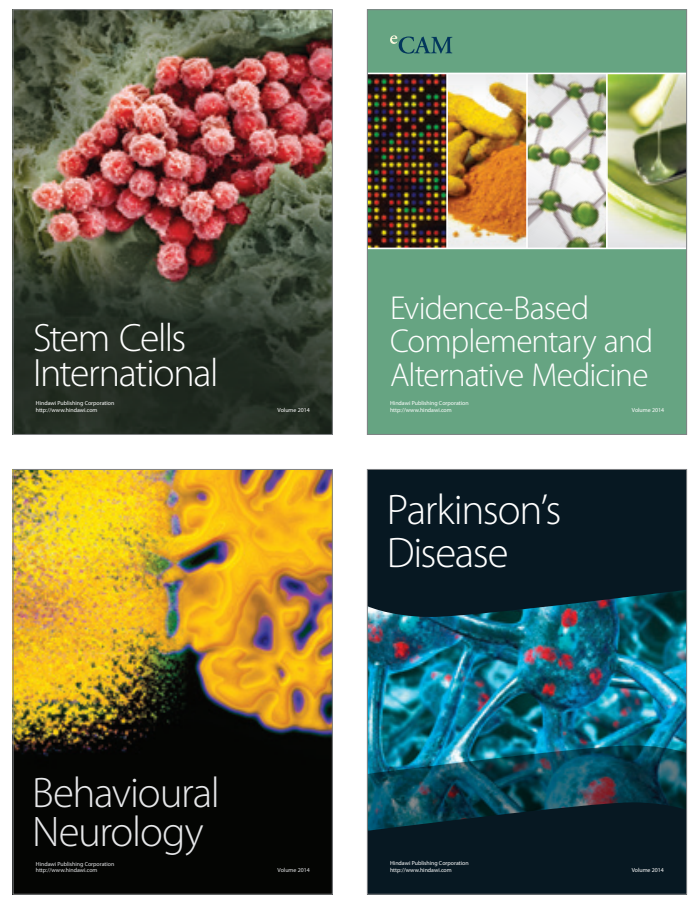
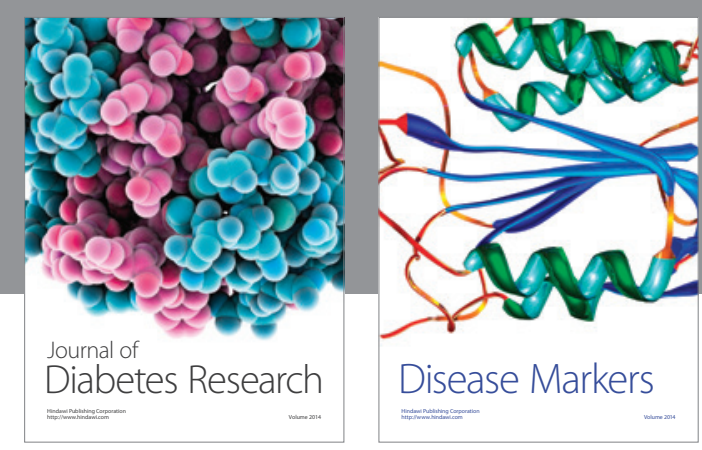

Disease Markers
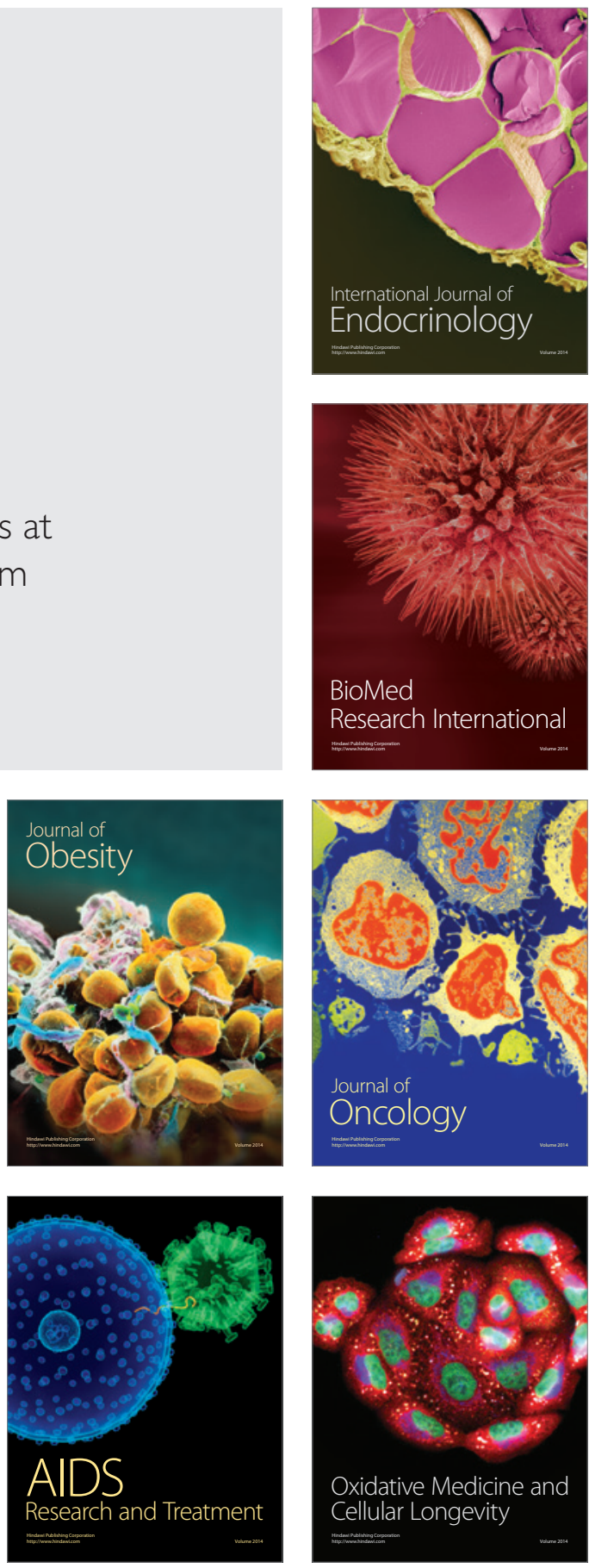